\title{
ASUHAN KEHAMILAN DALAM PERSPEKTIF BUDAYA JAWA DI DESA LABUHAN LABO KECAMATAN PADANGSIDIMPUAN TENGGARA KOTA PADANGSIDIMPUAN TAHUN 2015
}

\author{
Sri Juwarni \\ Prodi Kebidanan Padang Sidimpuan Poltekkes Medan
}

\begin{abstract}
Social and cultural conditions (customs) and environmental conditions (geographical conditions) affects reproductive health. Cultural situation this case customs at this time is not conducive for help seeking behavior in reproductive health issues in Indonesia. Java community strongly believe in myths developed by the predecessor. The Javanese culture for the community is an important thing,This study aims to determine pregnancy care in the perspective of Javanese culture the village of Labuhan Labo District of Southeast Padangsidimpuan Padangsidimpuan City. This type of research is qualitative descriptive study. Informants in this study is that people who understand the culture of Java in pregnancy care, amounting to 8 people. Collecting data using in-depth interviews conducted with, by means of data collection is interview, and a tape recorder. Results showed the care pregnancy in Labuhan Labo still influenced habit cultural of Java that includes 5 theme al: place and health services in the midwife and healer, the myth about the nutrition of pregnant women, the myth of pregnancy care with customs abdominal massage and seven monthly ritual, taboo / behavior of pregnant women and husband as well health information. Padangsidimpuan City Health Department, particularly the health center IV Pijorkoling Pal and related health team must give Information Education Communication (IEC) to Community appropriately, so to increase knowledge about pregnancy care in accordance the espoused culture. Shamans to follow skills in assisting the examination of pregnant women, in respect of utilizing the many people who still shaman in Antenatal care services in particular.
\end{abstract}

Keywords : Pregnancy, Pregnancy Care, Culture Java

\section{PENDAHULUAN}

Indikator kesejahteraan suatu bangsa salah satunya diukur dari besarnya angka kematian saat persalinan. Makin tinggi angka kematian tersebut, makin rendah kesejahteraan suatu bangsa. Selain menunjukkan derajad kesehatan masyarakat dan tingkat kesejahteraan masyarakat, juga menunjukkan kualitas pelayanan kesehatan. Di Indonesia angka kematian ibu masih merupakan masalah yang menjadi perioritas di bidang kesehatan (Hidayat dan Sujiatini, 2010).

Hasil Survey Demografi Kesehatan Indonesia (SDKI, 2012) menunjukkan, tingkat kematian ibu yang meningkat tajam dibandingkan dengan hasil survey SDKI pada tahun 2007. Angka Kematian Ibu (AKI) pada survey SDKI tahun 2012 sebanyak 359 per 100.000 kelahiran hidup sementara pada tahun 2007 sebesar 228 per 100.000 kelahiran hidup. Angka tersebut masih belum sesuai dengan kesepakatan Millenium Development Goals (MDGs) pada tahun 2015 yaitu 102 per 100.000 kelahiran hidup (Mulyani, 2014).

AKI di Propinsi Sumatera Utara pada tahun 2010 sebanyak 328/100.000 KH. Bila dibandingkan AKI Nasional, AKI Sumatera Utara cukup tinggi (AKI
Nasional sebanyak 259/100.000 KH), (Profil Kesehatan Sumatera Utara, 2012). AKI ini tidak mengalami penurunan sampai tahun 2013.Berdasarkan Profil Kesehatan Kota Padangsidimpuan terdapat jumlahkematian ibu pada Tahun 2013 sebanyak 7 orang diantaranya : 4 orang kematian pada saat hamil dan 3 orang pada saat persalinan.

Kondisi sosial budaya (adat istiadat) dan kondisi lingkungan (kondisi geografis) berpengaruh terhadap kesehatan reproduksi. Situasi budaya dalam hal ini adat istiadat saat ini memang tidak kondusif untuk help seeking behavior dalam masalah kesehatan reproduksi di Indonesia. Hal ini dikemukakan berdasarkan realita, bahwa masyarakat Indonesia pada umumnya sudah terbiasa menganggap bahwa kehamilan merupakan suatu hal yang wajar yang tidak memerlukan antenal care(perawatan/asuhan pada saat kehamilan). Hal ini tentu berkaitan pula dengan pengetahuan dan pemahaman masyarakat tentang pentingnya antenal care dan pemeliharaan kesehatan reproduksi lainnya (Muhammad, 1996).

Masyarakat Jawa sangat percaya dengan mitos-mitos yang dikembangkan oleh kaum pendahulunya. Budaya bagi masyarakat Suku Jawa adalah suatu hal yang penting, bahkan diantaranya 
dipercaya dan menjadi pegangan hidup oleh masyarakat. Untuk menjauhi berbagai masalah pada kehamilan tersebut ibu hamil Suku Jawa akan melakukan ritual yaitu 3 bulanan dan 7 bulanan, ritual ini dilakukan pada anak pertama dengan alasan, untuk tolak bala supaya memperoleh keselamatan, supaya dalam menjalani kehamilan merasa senang, termotivasi sehingga terhindar dari rasa cemas dan diharapkan dapat melalui proses kehamilan hingga persalinan berjalan dengan baik, lancar tanpa mengalami berbagai masalah (Notosoedirdjo, 1996).

Masyarakat Suku Jawa pada umumnya masih percaya pada mitos. Mitos tersebut sudah diyakini kebenarannya karena beberapa bukti yang terjadi. Masyarakat akan melakukan apa saja dengan harapan keselamatan pada ibu dan bayinya. Kadang kala kepercayaan tersebut bertentangan dengan nilai-nilai kesehatan medis modern, sehingga mengakibatkan permasalahan kesehatan pada ibu selama kehamilan.Mitos-mitos yang tidak ada hubungannya dengan kehamilan diantaranya tidak boleh makan dengan piring yang besar karena takut bayinya nanti besar dan sulit lahir (Azizah dkk, 2014).

Kebiasaan pijat perut saat hamil juga masih dilakukan. prilaku ini sangat membahayakan kesehatan baik pada ibu maupun pada janin. Dara (2013) mengungkapkan bahwa, "pijat perut waktu hamil untuk merubah posisi janin merupakan mitos belaka, sebaliknya pijat perut ini justru akan sangat membahayakan untuk perempuan terutama pada ibu hamil". Seluruh bagian tubuh lain boleh di urut atau dipijat "asalkan bukan perut". Di tambahkan Dara, perut merupakan bagian yang sangat sensitife bagi perempuan, karena organ-organ vital seperti usus, lambung, hati dan lain-lainnya semua terletak di bagian perut.

Percaya terhadap pantang makanan tertentu misalnyadaging kambing karena dapat mempersulit persalinan, bisa terjadi perdarahan. Pantang makanan tersebut sangat bertolak belakang dengan asuhan kebidanan yang selayaknya asupan nutrisi yang cukup sangat dibutuhkan untuk pertumbuhan janin disamping itu untuk kesehatan ibunya. Pantang makanan ini dilakukan dalam jangka waktu yang lama maka tidak bisa dipungkiri bahwa ibu hamil tersebut akan mengalami kekurangan gizi yang dapat mengakibatkan anemia selama kehamilan dimana sangat berkaitan dengan kejadian resiko perdarahan. Menurut WHO (2012), penyebab utama kematian ibu adalah penyebab obstetri langsung yaitu perdarahan berat $28 \%$ yang pada umumnya disebabkan anemia selama kehamilan, Kekurangan Energi Kronis (KEK), sedangkan penyebab AKI lainnya adalah Eklamsi 24\%, abortus (5\%), infeksi (11\%), Partus lama (5\%), Emboli obat (3\%), lain-lain (11\%), (Saptono I, 2013).

Warga Masyarakat Desa Labuhan Labo pada umumnya Suku Jawa masih melakukan berbagai tradisi jawa. Ibu Hamil di Desa Labuhan Labo dalam melakukan pemeriksaan kehamilan selain ke tenaga kesehatan juga dilakukan ke dukun, dimana dukun sangat dipercaya dalam memeriksa kehamilan.Data Puskesmas Pal IV Pijorkoling Wilayah Desa Labuhan Labo Kecamatan Padangsidimpuan Tenggara jumlah ibu hamil 621 jiwa dan yang mengalami resiko tinggi 124 jiwa $(25,1 \%)$ pada tahun 2013.Informasi yang diperoleh dari Dinas Kesehatan Kota Padangsidimpuan resiko tinggi ibu hamil tersebut yang paling banyak di temukan adalah: anemia selama kehamilan yang kemungkinann disebabkan oleh kurangnya asupan gizi dan suplemen zat besi saat hamil.

Survei pendahuluan yang dilakukan oleh peneliti di Desa Labuhan Labo Kecamatan Padangsidimpuan Tenggara pada bulan Januari tahun 2015 menemukan beberapa ibu hamil. Ibu hamil tersebut pemeriksaan kehamilannya ke bidan sesuai anjuran yang telah ditetapkan oleh pemerintah yaitu minimal 4 kali selama kehamilan tetapi masih ditemukan ibu hamil yang memeriksakan kehamilannya ke dukun, melakukan ritual adat istiadat, masih percaya terhadap kebiasaan (pijatan urut perut), mitos-mitos pantang makanan tertentu dan informasi dari bidan bahwa ada ibu hamil yang mengalami anemia yang kemungkinan akibat kurang mendapatkan nutrisi seimbang dalam jangka waktu yang lama.

Berdasarkan kondisi pada latar belakang tersebut maka diperlukan sebuah kajian tentang Asuhan Kehamilan dalam Perspektif BudayaJawa di Desa Labuhan Labo Kecamatan Padangsidimpuan Tenggara Kota Padangsidimpuan Tahun 2015.

Tujuan penelitian ini adalah untuk mengetahui asuhan kehamilan dalam perspektif budaya Jawa di Desa Labuhan Labo Kecamatan Padangsidimpuan Tenggara Kota Padangsidimpuan Tahun 2015.

\section{KERANGKA PIKIR}

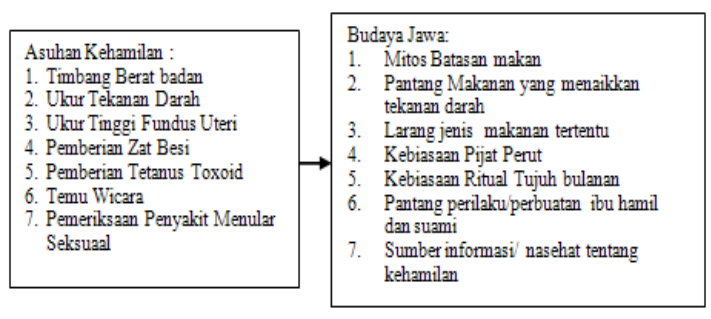

\section{METODE PENELITIAN}

Jenis penelitian yang digunakan adalah penelitian Deskriptif Kualitatif Fenomenologi. Informan pada penelitian ini adalah masyarakat yang memahami tentang budaya Jawa dalam asuhan kehamilan yang berjumlah 8 orang. Pengumpulan data dilakukan dengan wawancara mendalam. Penelitian ini dilakukan di Desa Labuhan Labo KecamatanPadangsidimpuan Tenggara, dengan alasan Penduduk desa Labuhan Labo mayoritas Suku Jawa (80\%). Penelitian ini dimulai dari bulan Februari tahun 2015 sampai Agustus tahun 2015. 


\section{METODE PENGUMPULAN DATA}

Pengumpulan data dalam penelitihan ini dilakukan dengan cara observasi, dokumentasi dan wawancara mendalamterhadap informan

\section{HASIL DAN PEMBAHASAN}

Berdasarkan Desa Labuhan Labo jumlah penduduk di Desa Labuhan Labo 1.467.000 jiwa dengan jumlah kepala keluarga 370 KK yang terdiri dari 712 jiwa penduduk laki-laki dan 755 jiwa penduduk perempuan serta mayoritas penduduk di desa Labuhan Labo adalah suku jawa (80\%) dari seluruh jumlah penduduk.

Tabel.1. Tenaga Kesehatan

\begin{tabular}{llc}
\hline & Tenaga Kesehatan & Jumlah (Orang) \\
\hline 1. & Bidan swasta & 1 \\
2. & Bidan Desa & 1 \\
\hline & Jumlah & $\mathbf{2}$ \\
\hline
\end{tabular}

Tabel.2. Karakteristik Informan

\begin{tabular}{ccccc}
\hline No & U th & Pdd & Pkj & Ket \\
\hline 1 & 24 & SLTA & Ibu RT & Hl \\
2 & 37 & SD & Ibu RT & H 3 \\
3 & 33 & SLTP & Ibu RT & H 3 \\
4 & 33 & SLTP & Ibu RT & H 2 \\
5 & 24 & SMK & Ibu RT & H 1 \\
6 & 23 & SLTP & Ibu RT & H 1 \\
7 & 63 & SD & Dukun & Dukun \\
8 & 27 & D-III Keb. & Bidan & Bidan desa \\
\hline
\end{tabular}

\section{BERDASARKAN HASIL PENELITIAN DITEMUKAN 5 TEMA AL:}

1. Tempat pemeriksaan dan pelayanan kesehatan ibu hamil,

2. Dilakukan dilakukan oleh bidan, di posyandu, pelayanan yang diberikan:

3. Penimbangan BB /TB, Pengukuran Tekanan Darah, Ukuran Lingkar Lengan Atas, Pengukuran Tinggi Fundus Uteri, Denyut Jantung Janin dan Pemberian Obat-obatan termasuk Tablet FE dan Suntikan Tetanus Neonatorum serta Penyuluhan/

4. Temuwicara.

Pemeriksaan ke dukun bayi dengan tujuan dapat memperbaiki letak kandungan dengan diurut-urut maka letak bayi yang salah bisa menjadi normal, kalau dengan bidan hanya menyarankan supaya lebih sering sujud agar bayinya berputar sendiri.

Biasanya ibu hamil memeriksakan kehamilannya ke dukun dulu,setelah itu ibu hamil mulai periksa kembali ke bidan setelah usia kehamilan 3 bulan setiap bulan di Posyandu sampai melahirkan. Timbang berat badan dan mengukur tinggi badan merupakan salah satu pelayanan kesehatan yang dilakukan dalam pemeriksaan kehamilan. Tujuannya adalah untuk mengetahui penambahan berat badan selama kehamilan, sehingga pertumbuhan janin dapat dimonitoring. Pemantauan berat badan penting dilakukan terutama pada ibu dengan kurang energi kronik karena berisiko terhadap terjadinya bayi berat lahir rendah dan perdarahan.

Rekomendasi penambahan berat badan selama kehamilan diberikan sesuai dengan Basal Metabolisme Indeks (BMI) ibu sebelum hamil, seperti pada ibu dengan BMI kurang dari 17,5 seharusnya penambahan berat badan selama kehamilan harus mencapai lebih dari $16 \mathrm{~kg}$, sedangkan ibu dengan kelebihan berat badan sebelum hamil penambahan berat badan tidak boleh lebih dari $7 \mathrm{~kg}$. Pemantauan bidan terhadap penambahan berat badan ibu selama hamil berkisar antara 8 sampai $10 \mathrm{~kg}$, hasil ini menunjukkan ibu hamil tidak mencapai berat badan yang seharusnya guna mencegah BBLR dan Perdarahan.

\section{Nutrisi Ibu Hamil}

\section{a. Mitos Batasan makan}

Pernyataan ibu hamil untuk menjaga berat badan normal harus makan dengan makan teratur, tidak boleh banyak-banyak, makannya sedikit saja, pesan dukun harus menahan selera makan, tidak boleh minum teh manis dan es banyak-banyak karena bisa gemuk. Beberapa ibu hamil juga menyatakan bahwa untuk menjaga supaya berat badan tidak berlebihan, maka makan cukup dengan satu sendok nasi dengan sayur, lauk tempe, tahu, ikan, dan buah-buahan. Kalau makannya berlebihan bisa menyebabkan bayinya besar dan dapat menyebab susah dalam melahirkan.

Pernyataan ibu hamil yang lain kalau mengkonsumsi makan yang banyak bisa menyebabkan gemuk dan mudah terserang banyak penyakit selain itu badan terlihat tidak bagus, lekas capek dan susah mengejan dalam melahirkan. Mereka menyatakan lebih bagus kecil bayinya dari pada besar supaya persalinannya lancar, jadi porsi makannya harus dikurangi, tidak boleh makan nasi terlalu banyak cukup satu centong nasi saja di tambah lauk ikan, tempe dan sayur.

\section{b.Mitos Pantang Makanan yang \\ Meningkatkan Tekanan Darah}

Hasil wawancara menjelaskan bahwa sebagian besar ibu hamil dilarang makan daging dan telur, ada juga yang boleh makan tetapi tidak berlebihan terutama daging kambing. Beberapa ibu hamil mengakui tidak boleh makan garam banyak karena dapat menaikan tekanan darah.

Menurut dukun bayi,ibu hamil tidak boleh makan daun singkong dan kol kemudian lauk yang dipantangkan seperti ikan asin, telur, daging sapi, dan daging kambingkarena jenis makanan ini dapat menaikan tensi. Begitu juga yang dikatakan bidan desa, ibu hamil yang dicurigai tensinya tinggi, tidak boleh makan daging khususnya daging kambing ataupun sejenis daging termasuk ayam.

\section{c. Mitos Larangan Jenis Makanan}

Wawancara selanjutnya untuk mengetahui Pantangan jenis makan pada ibu hamil. Hasil yang diperoleh yaitu: ada beberapa pantang makanan tertentu saat hamil, 
terutama hamil muda seperti tidak makan boleh duren karena panas takut keguguran, ketan-ketan walaupun hanya tepungnya takutnya lengket ari-ari, tidak boleh makan kikil takut arine (uri/plasenta) nya lengket.

\section{Perawatan Ibu Hamil \\ a. Kebiasaan Pijet Perut saat hamil}

Hasil penelitian diperoleh bahwa semua informan dalam perawatan kehamilannya masih melakukan pijat/kusuk ke dukun bayi, dengan tujuan untuk mengetahui letak bayi disamping itu juga untuk mendapatkan rasa nyaman. Dukun juga dianggap lebih mengerti masalah letak bayi dalam kandungan dari pada bidan. Informan lain ada yang mengatakan kalau dipijat saat hamil dapat berpengaruh pada pertumbuhan bayi dimana, pertumbuhan bayi makin baik, makin lancar peredaran darah asal tidak salah ngurutnya. Walaupun bidan sudah melarang, namun pijat perut ini tetap dilakukan, hal ini karena faktor kebiasaan yang turun-temurun dari orang tuanya, selain itu disebabkan ketidaktahuan informan dan dukun tentang bahaya pijet/kusuk terhadap kehamilan yag sangat beresiko.

\section{b. Kebiasaan Ritual Tujuh bulanan/Mitoni}

Selain kebiasaan diatas, ibu hamil suku jawa dalam melakukan perawatan kehamilan terutama pada hamil pertama melakukan adat Ritual Tujuh bulanan. Dari hasil wawancara diketahui seluruh informan melakukan ritual tersebut dengan cara mereka sendiri karena mereka berpendapat bahwa, acara tujuh bulanan adalah tradisi yang turun menurun dilakukan sampai sekarang walaupun dengan acara yang sangat sederahana dengan alasan ekonomi, ada rasa khawatir jika tidak dilakukan, karena melanggar adat, dan takut mendapat masalah pada proses kelahiran bayi, dan beberapa informan mengatakan bahwa membuat acara tujuh bulanan karena disuruh oleh mertuanya.

\section{PantangPerilaku pada Ibu \\ Hamil dan Suami}

Berdasarkan hasil wawancara dengan informan diketahui adanyaPantang perilaku/perbuatan pada ibu Hamil dan suami juga diakui oleh ibu hamil seperti kalau jalan ada kayu ditengah jalan harus diambil, tidak boleh disepak, tidak boleh dilangkahi supaya tidak menghambat jalan lahir bayinya. Ada juga pantangan yang lain kalau masakdengan bahan bakar kayu waktu masukan ke tungku tidak boleh di sepak karena bayinya bisa bahaya. Tidak boleh merendam kain takut air ketubannya banyak.

Beberapa ibu hamil mengatakan mereka disuruh menggunakan gunting, kunyit bungle dan bawang putih tunggal, ditusuk dengan peniti lalu digantungkan di baju yang dipakai supaya kalau pergi selalu bisa dibawa, untuk menjaga bayinya supaya sehat, tidak kena sawan, tidak diikuti setan, untuk menjaga dari makhluk halus atau sebagai tolak bala pada ibu dan bayinya. Tidak boleh keluar malam takut kena setan,tidak boleh duduk ditengah pintu karena dapat mempersulit kelahiran bayinya, kata orang tua nanti bisa menghambat bayinya susah keluar waktu melahirkan.

\section{Sumber Informasi tentang \\ Kehamilan}

Sumber informasi, nasehat tentang kehamilan diakui ibu hamil sering mereka dapat selain bidan, juga dari orang tua, suami, dan keluarga. Dukun mengatakan ketika istrinya hamil biasanya suami tambah sayang, sangat mendukung Sementara itu bidan desa mengatakan nasehat yang didapat oleh ibu hamil diperoleh dari orang tua, suami, bidan dan juga dari dukun. Dukungan yang diberikan tentang asuhan kehamilan agar ibu hamil mampu dan siap untuk menghadapi kehamilan dan persalianannya.

\section{KESIMPULAN}

Adapun kesimpulan dari penelitian ini adalah sebagai berikut :

1. Tempat pemeriksaan dan pelayanan kesehatan untuk ibu hamil dilakukan oleh bidan, namun ada informan yang memeriksa kehamilan ke tenaga bidan dan dukun bersama-sama, pelayanan ANC belum memenuhi standar 7T yaitu pelayanan pemeriksaan penyakit menular seksual dan pemeriksaan $\mathrm{Hb}$ karena fasilitas yang belum tersedia.

2. Adanya mitos larangan makan yang mengandung protein hewani dan nabati yang salah, sehingga mengganggu asupan gizi terutama kebutuhan akan zat besi yang merupakan salah satu factor penyebab anemia dan dapat mengakibatkan perdarahan saat proses persalinan

3. Adanya kebiasaan pijet perut saat hamil yang dilakukan dukun untuk membantu memperbaiki letak bayi, kebiasaan ini sangat merugikan kesehatan karena dapat membahayakan kandungan. Satu budaya yang sangat baik dipertahankan adalah Adat Mitoni/Tujuh bulanan karena makna yang terkandung sesuai kebutuhan fisik dan psikologis yang diperlukan oleh ibu saat hamil

4. Adanya pantangan perilaku ibu hamil seperti : tidak boleh duduk didepan pintu dll, hal ini tidak ada hubungannya dengan kehamilan dan proses proses persalinan.

5. Sumber informasi tentang Asuhan kehamilan didapat dari bidan, dukun dan keluarga (suami, orang tua, dan mertua)

Berbagai mitos budaya yang ada tersebut ada yang berdampak negatif dalam kehamilan yaitu mengurangi porsi makan, pantangan sumber protein hewani dan nabati, kebiasaan pijet perut.karena dapat mempengaruhi secara langsung terhadap kesehatan ibu dan janin. Budaya yang berdampak positif dalam kehamilan yaitu Ritual Tujuh bulanan. 


\section{SARAN}

Saran dalam penelitian ini yaitu diharapkan kepada :

1. Dinas Kesehatan Kota Padangsidimpuan, khususnya Puskesmas Pal IV Pijorkoling dan Tim Kesehatan terkait harus memberikan Komunikasi Informasi Edukasi (KIE) kepada Masyarakat dengan tepat, sehingga dapat meningkatkan pengetahuan tentang asuhan kehamilan sesuai dengan program kesehatan bukan berdasarkan pandangan kebudayaan yang dianut.

2. Bagi Pelayanan Kesehatan. Perlu peningkatan dan memberikan pelayanan yang lengkap sesuai program ANC (7T) yang telah ditetapkan dengan melibatkan peran serta keluarga dan masyarakat setempat

3. Dukun agar mengikuti keterampilan dalam membantu pemeriksaan ibu hamil, karena masih banyaknya masyarakat yang memanfaatkann jasa dukun dalam permeriksaan kehamilan

\section{DAFTAR PUSTAKA}

Asrinah dkk, 2010. Asuhan Kebidanan Masa Kehamilan, Yogyakarta: Graha Ilmu.

Azizah dkk, 2014. Segala tentang Mitos Ada di sini.Yogyakarta, Syurya Media Utama.

Achmad, 2014. Pamali dan Mitos Jawa Ilmu Kuno Yogyakarta, Araska.

Baston H, 2009. Midwifery Essentials Antenatal. EGC, Jakarta.

Dinas Kesehatan Sumatera Utara, 2012. Profil Kesehatan Sumatera Utara 2012.hhtp:/www.depkes.go.id/resources/donwload profil/profil_kes_propinsi_2012/

02/profil_kes_Prov Sumatera Utara-2012.pdf . Diakses tanggal 25 Maret 2015.
Dinas Kesehatan Propinsi Sumatera Utara, 2014. Profil Kesehatan Propinsi Sumatera Utara 2013. Dinas Kesehatan Propinsi Sumatera Utara, Medan.

Fauziah Cut A.2013.Mitos tentang Kehamilan. Prosiding International Conference of Indonesian Studies.Fakultas Ilmu Pengetahuan Budaya. Universitas Indonesia.

Moleong.R.J, 2009. Metode Penelitian Kualitatif Edisi Revisi. Bandung: Remaja Rosdakarya.

Rofi'I Muhammad, 2013 Kepercayaan Wanita Jawa tentang Perilaku atau Kebiasaanyang Dianjurkan dan Dilarang Selama Masa Kehamilan. Prosiding Konferensi Nasional PPNI Jawa Tengah.

Raffles T, 2014. The History Of Java.Alih bahasa Agustin dkk.Yogyakarta, NARASI.

Setyanti C,2013. Ibu Hamil Hendaknya Hindari Pijat Perut.famale. kompas.com/read/2013/05/21/21451610/Ibu.Sebai knya.Hindari.Pijat.Perut. Diakses23Pebruari 2015.

Sulistyoa Basuki, 2006. Metode Penelitian.Jakarta: Wedatama Widya Sastra dan Fakultas Ilmu Pengetahuan Budaya Universitas Indonesia.

Septiana, D, 2010. Gambaran Karakteristik,pengetahuan, Sikap dan Perilaku Ibu Hamil dalam Mendeteksi Risiko Tinggi di Puskesmas Kecamatan Pasar Rebo Jakarta Timur Tahun 2010. Skripsi, Fakultas Kesehatan Masyarakat Universitas Indonesia, Depok.

Syafrudin, Mariam, 2010. Sosial Budaya Dasar. Jakarta,Trans Info Media.

Swasono,MF,1998.Kehamilan, Kelahiran, Perawatan Ibu dan Bayi dalam Konteks Budaya. Jakarta, UI Press.

Widyastuti, P, 2003. Perawatan Ibu dan Bayi. EGC, Jakarta. 